\title{
Effect of Pot-Luck, Innovative Technique of Project-Based Learning, On Iranian EFL Learners' Autonomy in Learning
}

\author{
Hamideh Sadat Bagherzadeh (Corresponding author) \\ English Department, Islamic Azad University (IAU), Torbat-e Heydarieh Branch, Iran \\ E-mail: Hamidehbagherzadeh.hb@gmail.com
}

Khalil Motallebzadeh

English Department, Islamic Azad University (IAU), Torbat-e Heydarieh Branch, Iran

E-mail: k.motalleb@iautorbat.ac.ir

Hamid Ashraf

English Department, Islamic Azad University (IAU), Torbat-e Heydarieh Branch, Iran

E-mail: h.ashraf@iautorbat.ac.ir

Received: May 20, 2014 Accepted: June 2, 2014 Published: June 2, 2014

doi:10.5296/ijele.v2i2.5739 URL: http://dx.doi.org/10.5296/ijele.v2i2.5739

\begin{abstract}
The current study aims at investigating the effect of Pot-Luck, the creative idea of the researcher, as an innovative technique of Project-Based Learning, on Iranian EFL learners' autonomy in learning. The participants consisted of 52 upper-intermediate Iranian EFL learners in 2 groups of Experimental and Control. In order to collect data, three different instrumentations were utilized, including Autonomy questionnaire, Pot-luck survey, and Pot $\log$ (Pot-luck Weblog). The researchers used a quasi-experimental design with a pretesttreatment-posttest sequence. Having compared the mean scores and the t-test, the researcher found that there is a statistically significant difference between the pretest and posttest of the Experimental group. The qualitative data from the Pot-luck survey and Pot log also revealed that students enjoyed the course and developed a positive attitude towards Pot-luck and learning English in general by developing autonomous during the course. Therefore,
\end{abstract}


Pot-Luck, as an innovative technique of Project-Based Learning, has a significant effect on Iranian EFL learners' autonomy in learning; in addition, it helps students to enjoy and develop a positive attitude towards learning. As an implication of this study, Pot-Luck, the creative idea of the researcher, is introduced as an innovative technique of Project-Based Learning, which proved to be significantly effective in developing a positive attitude in learners towards learning, and improving autonomy in learning.

Keywords: Pot-luck, Project-Based learning, Effective learning, Innovative technique, Autonomy

\section{Introduction}

\subsection{Background and Purpose}

The critics of contemporary education have claimed that students do not master basic concepts and principles and cannot apply what they learn to everyday life (Finn, 1991). In the field of language learning, the researchers' personal learning and teaching experience as well as many other learners' and teachers' experience in an EFL context correspond to this fact that despite the teachers' effort in the classroom and the learners being bombarded by a huge amount of knowledge, most of the time, the outcome is not as satisfactory as expected, and that is just rote learning rather than deep meaning construction and effective learning. Therefore, as a member of ELT community, the researcher also felt this shared concern of EFL teachers regarding how it is possible to make the most of teaching by making learning effective and at the same time motivating, fun, and enjoyable. Moreover, she wondered how it is possible to involve learners in the process of learning by thinking deeply to make them autonomous and independent and prepare them for real life skills of the $21^{\text {st }}$ century. As a result, it was motivating enough for the researcher to focus on searching some possible solutions. Research shows that there are practices that will generally encourage students to be more engaged, feel more responsible, and develop autonomy. One way to approach this goal is to use project-based learning. The current research is the result of the researcher's findings on the effect of Pot-Luck, as an innovative technique of project-based learning, on Iranian EFL learners' autonomy in learning. The focus of the research is the effective learning by improving autonomy in order to learn important and essential skills of the $21^{\text {st }}$. Century.

John Thomas (2000) explains that project-based learning requires "complex tasks, based on challenging questions or problems that involve students in design, problem-solving, decision making, or investigative activities; give students the opportunity to work relatively autonomously over extended periods of time; and culminate in realistic products or presentations."

Many researchers believe that PBL is a beneficial learning model and in order to remediate its pitfalls, they have run intervention research proposing various strategies to support and improve it. Among the intervention strategies which have been proposed, the use of technology was central. (Kehoe et al., 1998) also clearly state that “... technology can play an important role in structuring and supporting effective project-based learning..." 
In this study, the researcher uses project-based learning with a special technique she calls "Pot-Luck". It is important to mention the whole idea of Pot-luck taken from the potluck gatherings, and using it as a project-based technique in the classroom has been just an innovative idea based on the researcher's creativity and innovation. It is important to mention Pot-log, "Pot-luck blog", as an intervention strategy of technology has been utilized in this study.

The specific research objectives of this study are twofold. Firstly, to investigate the effect of "Pot-luck" as an innovative technique of project-based learning on autonomy in learning, secondly, to represent the researcher's personal experience as an innovation in the implication of project-based learning.

\subsection{Statement of the Problem}

It seems that the ELT community suffers from the concern of how to make learning effective and practical so that it can prepare students for authentic life situations and utilization of the learning to gain $21^{\text {st }}$ century skills. Therefore, autonomy in learning, as one of the most important skills, seems very essential to master.

Today's students need to learn something beyond the rote knowledge, something more practical and effective. To this end, autonomy in learning is very crucial. By its nature, project-based learning is one of the possible ways of providing the opportunity for students to achieve that demanded knowledge and skills. This research by suggesting Pot-luck, as a new technique of project-based learning, brings new insights on how to make learners autonomous in order to make language learning effective and enjoyable.

\subsection{Significance of the Study}

Gaining autonomy in learning, which is one of the important skills needed for keeping the pace with others in $21^{\text {st }}$. Century, is a fact which cannot be ignored.

Considering the above-mentioned point, by sharing the findings of this research, on one side, the researcher tries to provide more evidence on the effect of project-based learning on autonomy in learning, and suggests "Pot-Luck"- the personal innovative experience of the researcher- as a technique of project-based learning, on the other side. Therefore, whoever interested in the effective learning and techniques of achieving it - especially in EFL contexts may find this study significant enough to follow.

\subsection{Research Question}

Q. Does "Pot-Luck" in EFL classes have any statistically significant effect on Iranian EFL learners' autonomy in learning?

\subsection{Research Hypothesis}

H. "Pot-Luck" in EFL classes does not have any statistically significant effect on Iranian EFL learners' autonomy in learning. 


\section{Review of Related Literature}

\subsection{Project-Based Learning}

2.1.1 Definition of Project-Based Learning. According to the Buck Institute for Education (BIE) (2012), in Project Based Learning (PBL), students go through an extended process of inquiry in response to a complex question, problem, or challenge. While allowing for some degree of student "voice and choice," rigorous projects are carefully planned, managed, and assessed to help students learn key academic content, practice 21st Century Skills (such as collaboration, communication \& critical thinking), and create high-quality, authentic products \& presentations.

If we are serious about reaching 21 st Century educational goals, PBL must be at the center of 21 st Century instruction. The project contains and frames the curriculum, which differs from the short "project" or activity added onto traditional instruction. PBL is, "The Main Course, not Dessert."(http://www.bie.org)

2.1.2 History of Project-Based Learning. According to the Buck Institute for Education (BIE) (2012), Project-Based learning has its roots in experiential education and the philosophy of John Dewey. The method of Project-Based learning emerged due to developments in learning theory in the past 25 years. The BIE suggests, "Because learning is a social activity, teaching methods can scaffold on students' prior experiences and include a focus on community and culture. Furthermore, because we live in an increasingly more technological and global society, teachers realize that they must prepare students not only to think about new information, but they also must engage them in tasks that prepare them for this global citizenship. Based on the developments in cognitive research and the changing modern educational environment in the latter part of the 20th Century, Project-Based learning has gained popularity.

Projects as a methodology are not a new concept; in the United States, pioneers were (Dewey, 1966) and (Kilpatrick, 1918).

These design ideas are based on various socio-constructivist schools of thought (Bruner, 1973), but can also be found in other modern instructional theories (Ausubel, Novak and Hanesian, 1978; Reigeluth, 1999).

2.1.3 Previous Research on Project-Based Learning. According to the Center of Excellence in Leadership of Learning (CELL) University of Indianapolis (2009), the summary of research on Project-Based Learning shows that overall, the research on Project-Based Learning (PBL) reports positive outcomes related to student learning in the areas of content knowledge, collaborative skills, engagement and motivation, and critical thinking and problem-solving skills. The studies suggest that Project-Based learning, when fully realized, can improve student learning. However, the research also underscores how difficult it is to implement Project-Based learning well.

2.1.3.1 PBL and content knowledge. PBL has several positive effects on students' content knowledge. Compared to traditional classes, students in PBL classes performed better on assessments of content knowledge (Boaler, 1997; Penuel \& Means, 2000; Stepien et al., 1993). 
Research also reported that PBL had a positive effect on specific groups of students. For example, students with average to low verbal ability and students with little previous content knowledge learned more in PBL classes than in traditional classes (Mergendoller et al., 2006; Mioduser \& Betzer, 2003). In addition, students were able to demonstrate specific content area skills after taking part in PBL (Mioduser \& Betzer, 2003; Peck et al., 1998). In summary, students taught in PBL classes emerged with useful, real-world content knowledge that they could apply to a variety of tasks (Boaler, 1997).

In his comprehensive review of the limited research on Project-Based learning, Thomas (2000) found some evidence that this approach enhances the quality of students' learning compared with other instructional methods. He also cited evidence that Project-Based learning is effective for teaching processes such as problem solving and decision making, but much of this research lacked comparisons with other methods.

2.1.3.2 PBL and learners' variables. PBL also has resulted in high levels of student engagement (Belland et al., 2006; Brush \& Saye, 2008). For instance, in one study within an economics classroom, a PBL unit engaged the lowest and highest level students as well as those students who were less interested in economics at the start of the unit (Ravitz \& Mergendoller, 2005).

Another study reported that PBL had a positive effect on student motivation to learn (Bartscher et al., 1995). According to elementary teachers, who reported using $37 \%$ of their overall instructional time on PBL, students' work ethics improved as well as their confidence and attitudes towards learning because of PBL (Tretten \& Zachariou, 1995).

Furthermore, Students who participated in PBL benefitted from improved critical thinking and problem-solving skills (Mergendoller et al., 2006; Shepherd, 1998; Tretten \& Zachariou, 1995). In particular, one study of PBL showed a positive effect on low-ability students, who increased their use of critical-thinking skills, including synthesizing, evaluating, predicting, and reflecting (Horan et al., 1996). Moreover, during PBL, students showed initiative by utilizing the resources and revising work, behavior that was uncharacteristic of them before engaging in PBL (Barron et al., 1998).

Attitude is often considered in educational research since the development of a positive attitude is desirable because of its association with achievement (Nkwe, 1985). Ma and Kishor (1997) indicated there is a general belief that children learn more effectively when they are interested in what they learn and that they will achieve better in mathematics if they like mathematics.

A number of researchers have demonstrate that there is a significant correlation between attitude and achievement (Aiken, 1976; Davis, 2002; Haladyna, Shaughnessy, \& Shaughnessy, 1983; Kulm, 1980; Ma, 1997; Ma \& Kishor, 1997; Schoenfeld, 1989; White, 2001)

\section{Methodology}

\subsection{Participants}

The participants consist of 52 upper intermediate Iranian EFL learners from a Language Institute in Mashhad, Iran; in one Treatment group of (PBL utilizing the 
researcher-creatively-made innovative technique of Pot-Luck) and one Control group (using PBL) in order to reduce the effect of selection bias. They were the available sample from upper intermediate students, both girls and boys with the average age of 22 . Gender was not a variable of the study.

\subsection{Instrumentation}

In order to gather the data, three instruments were used in the study: an autonomy questionnaire, the Pot-luck survey, and Pot log, Pot-luck blog. Detailed information about these instruments is stated below.

3.2.1 Autonomy questionnaire. In order to measure the autonomy level of the learners to investigate whether Pot-Luck, as a creative technique of Project-Based learning, has made any difference in the learners' level of autonomy or not, a researcher-made questionnaire (see Appendix 1) was utilized prior to the treatment. The same questionnaire repeated at the end of the treatment. The questionnaire had two parts with a total number of 36 questions measuring the learners' level of autonomy in taking the initiative, taking responsibility, using technology, and feeling independent. The time allocated to filling out this questionnaire was 15 minutes approximately.

The reliability of the questionnaire was checked by piloting it in a smaller sample. Utilizing Alpha Cronbach, the reliability was 0.91 . The validity of the questionnaire was also checked by two TEFL university teachers, and three IELTS and TOEFL teachers in a language institute in terms of appropriateness of the content, feasibility, and practicality.

3.2.2 Pot-luck Survey. The Pot-luck Survey (see Appendix 2), developed by the researcher and included six open-ended questions. Five items (1 - 2 - 3 - 4- 5) were designed for the learners to get an assessment of themselves regarding the effectiveness of their achievement and the autonomy in learning, and the other item (6) was an open-ended question, provided for the learners' criticism, opinions, and suggestions about Pot-luck, as an innovative technique of the project-based learning, and self-assessment of their own work. The time allocated to this survey was 10 minutes, a bit more than needed to let the learners express themselves freely. The researcher used this survey just in the treatment group; therefore, it is both for self-assessment of their own work and sort of feedback for the researcher. Since at the beginning of the course the learners did not have any ideas of Pot-luck; therefore, this survey was given to the students at the end of the treatment as a post-test. The survey was checked by two TEFL university teachers and three IELTS and TOEFL teachers in a language institute in terms of content validity and appropriateness.

3.2.3 Pot-Log (Pot-luck Web log). Pot-log was an educational blog (see Appendix 3) as an outside-the-classroom feeding source of information and a resort for the students and teachers to share their ideas and care about each other's problems. It had different pages and different posts which helped students feel responsible and autonomous for their language learning problems and even others' problems. 


\subsection{Procedure}

In this study project-based learning was conducted by Pot-luck, a special creative technique of the researcher, based on the idea of Pot-luck gatherings. The aim of the study was to investigate the effect of Pot-luck, as an innovative technique of project- based learning, on Iranian EFL learners' autonomy in learning. To utilize the idea, special lesson plans were developed by the researcher considering the criteria of project-based learning and the guidance of some university professors and PBL researchers inside and outside of Iran.

Before going through the process, the researcher is willing to mention that by "Pot-luck" she means a meal in which everyone who is invited brings something to eat; therefore, everyone shares the meal, or shares the ingredients of the meal.

As in project-based learning there should be a problem to be dealt with, in this project the authentic problem is autonomy in learning English- specifically speaking skill- for Iranian EFL learners and the skill or technique students apply to solve the problem is "Pot-luck Time", it is a time through whole class at the beginning of each part of the lesson. In this time through pair work and group work, in collaborative problem solving activities first, students discover the problems, then participate and engage actively in solving the problems; it is worth mentioning that besides the Pot-luck Time in the class, learners also have Pot-luck Time out of the class in virtual environment of Pot-log, which is Pot-luck blog and even other virtual situations like face book or learners' personal blogs. A sample class session is as follows:

The teacher describes Pot-luck gatherings to the students and tells them at the beginning of every part of the lesson they have a Pot-luck gathering, but the difference of this Pot-luck with the real one is that the lesson is like the main dish and every part of the lesson is like ingredients of the main dish, so every students who comes to class should bring something, it means that they come to class prepared on all the parts or at least on one part of the lessons .To facilitate the recognition of what each students brought to class, they have some labels that show it. The labels can be related to different skills and strategies of learning (in this study speaking skill) or even vocabulary, grammar, pronunciation, accent, presentation skills, self-confidence, etc. For example if one student comes to class with pronunciation label, it means that this student is ready to help others in pronunciation by sharing his/her knowledge or techniques and strategies, and if a student has a grammar label, it means that he/she can help others with grammar, both grammatical problems and improving strategies. In our course, since it was a speaking skill course, students come with the labels related to speaking skills and strategies. It is important to mention even if there is a student or some students that for any reasons come to class empty-handed or who are not willing to share something, or even if they are intrapersonal, $\mathrm{s} /$ he can at least listen to others, get some ideas peripherally and then work alone or just use the Pot-luck time for self -improvement and independence. For speaking part or panel discussion for example, the teacher asks the students to share some real life problems, then have some reflection time, then group sharing, and at the end suggesting the solution they came up with. Sometimes the problems are related to language learning, like what is the best way to learn vocabulary and sometimes related to other areas like how to apply for a foreign university; therefore, like sharing food, they share their ideas and information; therefore, they have a 
critical thinking time to some extent. Students also utilize the ideas in Pot log, Pot-luck blog, they can also share ideas in advance, or continue sharing ideas, discussion, and solution to their problems out of the class, in online virtual situations. The teacher is away from students just monitoring them and giving them help if needed in order to pave the way for them to develop independent and autonomous.

The Pot-luck project-based learning course in this study lasted five weeks (fifteen 90-minute class sessions) along with the control group during the summer semester 2013. The goal of the research was to utilize Pot-luck, as the researcher-creatively-made innovative technique of project-based learning, in order to help students to feel responsible for their problems of language learning -especially speaking skill problems- to take initiative actions, and autonomously take part in learning projects to encourage them by sharing their learning problems and taking care of their problems in sharing and caring activities in Pot-luck time in order to be able to solve their problems, improve their skills, and improve autonomy in learning which is one of the most important $21^{\text {st }}$. Century life skills.

On the other hand, the learners in the control group had the same treatment except for the Pot-luck aspect. That is the learners in the control group were also helped to solve their learning problems- especially speaking skill problems - and improve their autonomy via project-based learning program. They were also encouraged to feel responsible and try to autonomously take part in collaborative projects. The only difference was that they did not utilize Pot-luck technique.

\section{Results and Data Analysis}

\subsection{Descriptive Statistics}

4.1.1 Descriptive Statistics of the Autonomy Questionnaire (Part 1).

4.1.1.1 The results of the Autonomy Questionnaire Pre-Test and Post-Test in control group.

Table 1. Descriptive statistics of the pre and post autonomy questionnaire for control group

\begin{tabular}{|l|l|l|}
\hline Number & Pretest Mean & Posttest Mean \\
\hline 1 & 1 & 2.34 \\
\hline 2 & 1.21 & 2.35 \\
\hline 3 & & \\
\hline 4 & 2.45 & 2.70 \\
\hline 5 & 2.13 & 2.45 \\
\hline 6 & 1.56 & 1.88 \\
\hline 7 & 1.22 & 2 \\
\hline 8 & 2.10 & 2.34 \\
\hline 9 & 1.45 & 2.70 \\
\hline 10 & 2.66 & 2.90 \\
\hline 11 & 2.34 & 2.88 \\
\hline 12 & 3.00 & 3.32 \\
\hline
\end{tabular}




\begin{tabular}{|l|l|l|}
\hline Number & Pretest Mean & Posttest Mean \\
\hline 13 & 2 & 2.55 \\
\hline 14 & 1.17 & 2.33 \\
\hline 15 & 1.90 & 2.45 \\
\hline 16 & 1.28 & 1.90 \\
\hline 17 & 0.98 & 1.55 \\
\hline 18 & 2.22 & 2.58 \\
\hline 19 & 2.53 & 2.78 \\
\hline 20 & 2.22 & 2.95 \\
\hline 21 & 1.68 & 2 \\
\hline 22 & 0.85 & 1.45 \\
\hline 23 & 1.04 & 1.89 \\
\hline 24 & 2.33 & 2.64 \\
\hline 25 & 1.14 & 1.88 \\
\hline
\end{tabular}

Comparing the mean scores of pre-test and post-test of control group in Table1, the mean scores of post-test scores were higher than the pre-test scores for control group.

4.1.1.2 The results of the Autonomy Questionnaire Pre-Test and Post-Test in experimental group.

Table 2. Descriptive statistics of the pre and post autonomy questionnaire for experimental group (part 1)

\begin{tabular}{|l|l|l|}
\hline Number & Pretest Mean & Posttest Mean \\
\hline 1 & 1.44 & 4.64 \\
\hline 2 & 1.40 & 4.66 \\
\hline 3 & 3.15 & 3.11 \\
\hline 4 & 3.03 & 3.40 \\
\hline 5 & 1.36 & 4.60 \\
\hline 6 & 1.55 & 4.64 \\
\hline 7 & 3.07 & 3.69 \\
\hline 8 & 1.38 & 4.43 \\
\hline 9 & 3.17 & 3.30 \\
\hline 10 & 3.09 & 3.34 \\
\hline 11 & 3.05 & 3.15 \\
\hline 12 & 1.40 & 4.49 \\
\hline 13 & 2.25 & 3.24 \\
\hline 14 & 1.36 & 4.73 \\
\hline 15 & 2.42 & 3.24 \\
\hline 16 & 1.32 & 4.60 \\
\hline 17 & 1.38 & 4.71 \\
\hline 18 & 3 & 3.30 \\
\hline 19 & 3.26 & 3.52 \\
\hline
\end{tabular}




\begin{tabular}{|l|l|l|}
\hline Number & Pretest Mean & Posttest Mean \\
\hline 20 & 3.02 & 3.45 \\
\hline 21 & 2.23 & 3.37 \\
\hline 22 & 1.23 & 4.86 \\
\hline 23 & 1.40 & 4.96 \\
\hline 24 & 3.11 & 3.71 \\
\hline 25 & 1.34 & 4.84 \\
\hline
\end{tabular}

Comparing the mean scores of pre-test and post-test of experimental group in Table 2, the mean scores of post-test scores were higher than the pre-test scores for experimental group. The dramatic change of the average of scores in Post-Test compared with Pre-Test especially in questions $(1,2,5,6,8,12,14,16,17,22,23$, and 25), indicates that the students' autonomy in experimental group has increased dramatically.

\subsubsection{Descriptive Statistics of the Autonomy Questionnaire (Part 2).}

4.1.2.1 The results of the Autonomy Questionnaire (Part 2- Q1) Pre-Test and Post-Test in control and experimental groups.

Table 3. Descriptive statistics of the pre and post autonomy questionnaire for control group (Part 2/ Question 1)

\begin{tabular}{|l|l|l|l|l|l|}
\hline Question 1 & Option 1 & Option 2 & Option 3 & Option 4 & Option 5 \\
\hline Pretest & 0.53 & 0.53 & 0.5 & 0.53 & 0.46 \\
\hline Posttest & 0.46 & 0.5 & 0.42 & 0.69 & 0.5 \\
\hline
\end{tabular}

Table 4. Descriptive statistics of the pre and post autonomy questionnaire for experimental group (Part 2/ Question 1)

\begin{tabular}{|l|l|l|l|l|l|}
\hline Question 1 & Option 1 & Option 2 & Option 3 & Option 4 & Option 5 \\
\hline Pretest & 0.46 & 0.53 & 0.5 & 0.42 & 0.53 \\
\hline Posttest & 0.34 & 0.38 & 0.34 & 0.80 & 0.30 \\
\hline
\end{tabular}

Comparing the mean scores of pre-test and post-test of control and experimental groups in Table 3 and Table 4, it was clear that in posttest in experimental group as well as control group; most of the students have chosen option 4. Choosing option 4 (Being interested in English culture, such as films, sports, music, etc.) as the reason of studying English, indicates that after the treatment the students became more interested in learning English and they develop a positive attitude towards learning English.

4.1.2.3 The results of the Autonomy Questionnaire (Part 2-Q2) Pre-Test and Post-Test in control and experimental groups.

Table 5. Descriptive statistics of the pre and post autonomy questionnaire for control group (Part 2/ Question 2)

\begin{tabular}{|l|l|l|l|l|l|}
\hline Question 2 & Option 1 & Option 2 & Option 3 & Option 4 & Option 5 \\
\hline Pretest & 0.5 & 0.46 & 0.53 & 0.65 & 0.42 \\
\hline
\end{tabular}




\begin{tabular}{|l|l|l|l|l|l|}
\hline Posttest & 0.34 & 0.38 & 0.46 & 0.42 & 0.57 \\
\hline
\end{tabular}

Table 6. Descriptive statistics of the pre and post autonomy questionnaire for experimental group (Part 2/ Question 2)

\begin{tabular}{|l|l|l|l|l|l|}
\hline Question 2 & Option 1 & Option 2 & Option 3 & Option 4 & Option 5 \\
\hline Pretest & 0.46 & 0.38 & 0.53 & 0.5 & 0.46 \\
\hline Posttest & 0.34 & 0.30 & 0.26 & 0.5 & 0.80 \\
\hline
\end{tabular}

Comparing the mean scores of pre-test and post-test of control and experimental groups in Table 5 and Table 6, it was clear that in posttest most of the students have chosen option 5. Choosing option 5 (Explorer and director) as the answer of students for their opinion on learner-teacher relationship, indicates that after the treatment in experimental group as well as control group the students attitude towards the learner-teacher relationship changed from traditional views towards more modern views.

\subsubsection{The results of the Autonomy Questionnaire (Part 2-Q3) Pre-Test and Post-Test in} control and experimental groups.

Table 7. Descriptive statistics of the pre and post autonomy questionnaire for control group (Part 2/ Question 3)

\begin{tabular}{|l|l|l|l|l|l|}
\hline Question 3 & Option 1 & Option 2 & Option 3 & Option 4 & Option 5 \\
\hline Pretest & 0.65 & 0.53 & 0.61 & 0.65 & 0.34 \\
\hline Posttest & 0.57 & 0.46 & 0.53 & 0.5 & 0.46 \\
\hline
\end{tabular}

Table 8 . Descriptive statistics of the pre and post autonomy questionnaire for experimental group (Part 2/ Question 3)

\begin{tabular}{|l|l|l|l|l|l|}
\hline Question 3 & Option 1 & Option 2 & Option 3 & Option 4 & Option 5 \\
\hline Pretest & 0.57 & 0.53 & 0.57 & 0.57 & 0.5 \\
\hline Posttest & 0.30 & 0.26 & 0.34 & 0.23 & 0.84 \\
\hline
\end{tabular}

Comparing the mean scores of pre-test and post-test of control and experimental groups in Table 7 and Table 8, it was clear that in posttest most of the students have chosen option 5. It is noteworthy to mention that the answer of students to this question is one of the examples that obviously indicate that their sense of autonomy has increased after the treatment. Choosing option 5 (Myself) as the answer of students for their opinion on the reason of their success or failure in English studies, indicates this fact very clearly.

\subsubsection{The results of the Autonomy Questionnaire (Part 2-Q4) Pre-Test and Post-Test in control and experimental groups.}

Table 9. Descriptive statistics of the pre and post autonomy questionnaire for control group (Part 2/ Question 4)

\begin{tabular}{|l|l|l|l|l|l|}
\hline Question 4 & Option 1 & Option 2 & Option 3 & Option 4 & Option 5 \\
\hline Pretest & 0.34 & 0.53 & 0.5 & 0.53 & 0.53 \\
\hline Posttest & 0.57 & 0.46 & 0.46 & 0.42 & 0.42 \\
\hline
\end{tabular}


Table 10. Descriptive statistics of the pre and post autonomy questionnaire for experimental group (Part 2/ Question 4)

\begin{tabular}{|l|l|l|l|l|l|}
\hline Question 4 & Option 1 & Option 2 & Option 3 & Option 4 & Option 5 \\
\hline Pretest & 0.57 & 0.46 & 0.57 & 0.53 & 0.5 \\
\hline Posttest & 0.88 & 0.30 & 0.38 & 0.34 & 0.38 \\
\hline
\end{tabular}

Comparing the mean scores of pre-test and post-test of control and experimental groups in Table 9 and Table 10, it was clear that in posttest most of the students have chosen option 1. It is noteworthy to mention that choosing option 1 (Strongly agree) as the answer of students for their opinion on whether students should design the teaching plan together with teachers or not, indicates that after the treatment the students felt more autonomous and responsible for their learning.

4.1.2.9 The results of the Autonomy Questionnaire (Part 2-Q5) Pre-Test and Post-Test in control and experimental groups.

Table 11. Descriptive statistics of the pre and post autonomy questionnaire for control group (Part 2/ Question 5)

\begin{tabular}{|l|l|l|l|l|l|}
\hline Question 5 & Option 1 & Option 2 & Option 3 & Option 4 & Option 5 \\
\hline Pretest & 0.5 & 0.65 & 0.5 & 0.53 & 0.34 \\
\hline Posttest & 0.34 & 0.57 & 0.5 & 0.42 & 0.57 \\
\hline
\end{tabular}

Table 12. Descriptive statistics of the pre and post autonomy questionnaire for experimental group (Part 2/ Question 5)

\begin{tabular}{|l|l|l|l|l|l|}
\hline Question 5 & Option 1 & Option 2 & Option 3 & Option 4 & Option 5 \\
\hline Pretest & 0.5 & 0.38 & 0.53 & 0.57 & 0.53 \\
\hline Posttest & 0.30 & 0.26 & 0.38 & 0.38 & 0.84 \\
\hline
\end{tabular}

Comparing the mean scores of pre-test and post-test of control and experimental groups in Table 11 and Table 12, it was clear that in posttest most of the students have chosen option 5. It is noteworthy to mention that choosing option 5 (Join a pair/group discussion) as the answer of students for their opinion on what they mostly like to do when the teacher asks a question, indicates that after the treatment in experimental group as well as control group the students not only felt more autonomous and responsible for their learning, but also for the other students' and their group's learning. This point actually is affected by the fact that the course and the treatment they got was project-based learning and they mostly worked on groups.

4.1.2.11 The results of the Autonomy Questionnaire (Part 2- Q6) Pre-Test and Post-Test in control and experimental groups.

Table 13. Descriptive statistics of the pre and post autonomy questionnaire for control group (Part2 / Question 6)

\begin{tabular}{|l|l|l|l|l|l|}
\hline Question 6 & Option 1 & Option 2 & Option 3 & Option 4 & Option 5 \\
\hline
\end{tabular}




\begin{tabular}{|l|l|l|l|l|l|}
\hline Pretest & 0.57 & 0.53 & 0.53 & 0.46 & 0.76 \\
\hline Posttest & 0.53 & 0.46 & 0.34 & 0.61 & 0.42 \\
\hline
\end{tabular}

Table 14. Descriptive statistics of the pre and post autonomy questionnaire for experimental group (Part 2/ Question 6)

\begin{tabular}{|l|l|l|l|l|l|}
\hline Question 6 & Option 1 & Option 2 & Option 3 & Option 4 & Option 5 \\
\hline Pretest & 0.46 & 0.46 & 0.42 & 0.42 & 0.57 \\
\hline Posttest & 0.26 & 0.38 & 0.34 & 0.88 & 0.30 \\
\hline
\end{tabular}

Comparing the mean scores of pre-test and post-test of control and experimental groups in Table 13 and Table 14, it was clear that in posttest most of the students have chosen option 4. It is noteworthy to mention that choosing option 4 (2 and 5) (2.Ask others) and (5.Search and try to find the answer by myself) as the answer of students to the question what they do when they meet a question they don't know, indicates that after the treatment the students not only got more autonomous but collaborative because their answer covers both autonomy and collaboration.

4.1.2.13 The results of the Autonomy Questionnaire (Part 2-Q7) Pre-Test and Post-Test in control and experimental groups.

Table 15. Descriptive statistics of the pre and post autonomy questionnaire for control group (Part 2/ Question 7)

\begin{tabular}{|l|l|l|l|l|l|}
\hline Question 7 & Option 1 & Option 2 & Option 3 & Option 4 & Option 5 \\
\hline Pretest & 0.46 & 0.34 & 0.5 & 0.5 & 0.5 \\
\hline Posttest & 0.38 & 0.53 & 0.42 & 0.38 & 0.42 \\
\hline
\end{tabular}

Table 16. Descriptive statistics of the pre and post autonomy questionnaire for experimental group (Part 2/ Question 7)

\begin{tabular}{|l|l|l|l|l|l|}
\hline Question 7 & Option 1 & Option 2 & Option 3 & Option 4 & Option 5 \\
\hline Pretest & 0.53 & 0.46 & 0.57 & 0.46 & 0.5 \\
\hline Posttest & 0.34 & 0.84 & 0.38 & 0.38 & 0.34 \\
\hline
\end{tabular}

Comparing the mean scores of pre-test and post-test of control and experimental groups in Table 15 and Table 16, it was clear that in posttest most of the students in experimental group as well as control group have chosen option 2 . It is noteworthy to mention that choosing option 2 (Teachers) as the answer of students to the question who they like to correct them when they make a mistake, indicates an interesting point and of course reveals a reality about the mindset of Iranian students that even after a lot of sharing and caring activities in the treatment, the students still have their typical traditional view of teacher as the main source of knowledge. Not to mention, other questions show that they improved their autonomy but still they have some traditional views. As a matter of fact, it is natural that changing the whole students' mindset which has shaped in a traditional educational system is a very demanding and strenuous task which cannot be met overnight just by a short period of treatment; nevertheless, managing to start a change was very satisfactory for the researcher. 
4.1.2.15 The results of the Autonomy Questionnaire (Part 2-Q8) Pre-Test and Post-Test in control and experimental groups.

Table 17. Descriptive statistics of the pre and post autonomy questionnaire for control group (Part 2/ Question 8)

\begin{tabular}{|l|l|l|l|l|l|}
\hline Question 8 & Option 1 & Option 2 & Option 3 & Option 4 & Option 5 \\
\hline Pretest & 0.42 & 0.46 & 0.5 & 0.53 & 0.46 \\
\hline Posttest & 0.57 & 0.34 & 0.46 & 0.5 & 0.38 \\
\hline
\end{tabular}

Table 18. Descriptive statistics of the pre and post autonomy questionnaire for experimental group (Part 2/ Question 8)

\begin{tabular}{|l|l|l|l|l|l|}
\hline Question 8 & Option 1 & Option 2 & Option 3 & Option 4 & Option 5 \\
\hline Pretest & 0.42 & 0.34 & 0.53 & 0.46 & 0.42 \\
\hline Posttest & 0.84 & 0.26 & 0.34 & 0.38 & 0.30 \\
\hline
\end{tabular}

Comparing the mean scores of pre-test and post-test of control and experimental groups in Table 17 and Table 18, it was clear that in posttest most of the students have chosen option 1. It is noteworthy to mention that choosing option 1 (I usually try to learn new skills) as the answer of students to the question of asking their feeling about the time when they are asked to use technologies that they have not used before(e. g. internet discussion in the class forum) and comparing it with the answer of the students in pretest that was mostly option 3 (I feel worried, but anyway) and option 4 (I put it off or try to avoid it) reveals that after the treatment period in experimental group as well as control group most of the students changed from being a technophobe to a technophile (e.g. more technology friendly).

4.1.2.17 The results of the Autonomy Questionnaire (Part 2-Q9) Pre-Test and Post-Test in control and experimental groups.

Table 19. Descriptive statistics of the pre and post autonomy questionnaire for control group (Part 2/ Question 9)

\begin{tabular}{|l|l|l|l|l|l|}
\hline Question 9 & Option 1 & Option 2 & Option 3 & Option 4 & Option 5 \\
\hline Pretest & 0.53 & 0.38 & 0.5 & 0.42 & 0.53 \\
\hline Posttest & 0.61 & 0.5 & 0.38 & 0.53 & 0.42 \\
\hline
\end{tabular}

Table 20. Descriptive statistics of the pre and post autonomy questionnaire for experimental group (Part 2/ Question 9)

\begin{tabular}{|l|l|l|l|l|l|}
\hline Question 9 & Option 1 & Option 2 & Option 3 & Option 4 & Option 5 \\
\hline Pretest & 0.65 & 0.61 & 0.42 & 0.46 & 0.46 \\
\hline Posttest & 0.92 & 0.26 & 0.38 & 0.30 & 0.42 \\
\hline
\end{tabular}

Comparing the mean scores of pre-test and post-test of control and experimental groups in Table 19 and Table 20, it was clear that in posttest most of the students have chosen option 1. It is noteworthy to mention that choosing option 1 (try to post some comments, or share my information or experience with others) as the answer of students to the question of asking 
their feeling about the time when they are asked to use technologies (e. g. our class blog "Pot-Log" or our class face book page), reveals that after the treatment period most of the students changed from being a technophobe to a technophile (e.g. more technology friendly). Besides, this change in experimental group was more noticeable than control group.

4.1.2.19 The results of the Autonomy Questionnaire (Part 2-Q10) Pre-Test and Post-Test in control and experimental groups.

Table 21. Descriptive statistics of the pre and post autonomy questionnaire for control group (Part 2/ Question 10)

\begin{tabular}{|l|l|l|l|l|l|}
\hline Question 10 & Option 1 & Option 2 & Option 3 & Option 4 & Option 5 \\
\hline Pretest & 0.5 & 0.46 & 0.53 & 0.57 & 0.38 \\
\hline Posttest & 0.42 & 0.42 & 0.57 & 0.5 & 0.61 \\
\hline
\end{tabular}

Table 22. Descriptive statistics of the pre and post autonomy questionnaire for experimental group (Part 2/ Question 10)

\begin{tabular}{|l|l|l|l|l|l|}
\hline Question 10 & Option 1 & Option 2 & Option 3 & Option 4 & Option 5 \\
\hline Pretest & 0.46 & 0.38 & 0.53 & 0.5 & 0.42 \\
\hline Posttest & 0.30 & 0.26 & 0.34 & 0.23 & 0.84 \\
\hline
\end{tabular}

Comparing the mean scores of pre-test and post-test of control and experimental groups in Table 21 and Table 22, it was clear that in posttest most of the students have chosen option 5. It is noteworthy to mention that choosing option 5 (Group discussion) as the answer of students to the question of asking their opinion about the most useful way in their English study, indicates that after the treatment period they develop autonomous to take responsibility over their learning and even initiative roles in group discussion to collaborate for learning better. Moreover, this increase compared with the control group is more noticeable.

\subsubsection{The results of the Autonomy Questionnaire (Part 2- Q11) Pre-Test and Post-Test in control and experimental groups.}

Table 23. Descriptive statistics of the pre and post autonomy questionnaire for control group (Part 2/ Question 11)

\begin{tabular}{|l|l|l|l|l|l|}
\hline Question 11 & Option 1 & Option 2 & Option 3 & Option 4 & Option 5 \\
\hline Pretest & 0.46 & 0.53 & 0.34 & 0.46 & 0.76 \\
\hline Posttest & 0.38 & 0.46 & 0.57 & 0.42 & 0.42 \\
\hline
\end{tabular}

Table 24. Descriptive statistics of the pre and post autonomy questionnaire for experimental group (Part 2/ Question 11)

\begin{tabular}{|l|l|l|l|l|l|}
\hline Question 11 & Option 1 & Option 2 & Option 3 & Option 4 & Option 5 \\
\hline Pretest & 0.46 & 0.53 & 0.5 & 0.42 & 0.53 \\
\hline Posttest & 0.34 & 0.38 & 0.80 & 0.26 & 0.30 \\
\hline
\end{tabular}

Comparing the mean scores of pre-test and post-test of control and experimental groups in Table 23 and Table 24, it was clear that in posttest most of the students have chosen option 3. 
It is noteworthy to mention that choosing option 3 (by teachers and by myself) as the answer of students to the question of asking their opinion about their preference of chosen material, indicates that after the treatment period they develop autonomous to take responsibility over their learning by considering themselves responsible in choosing the material; therefore, their traditional look in this case has changed to the extent that they do not consider the teacher as the only responsible one for the material and they feel themselves as well involved as the teacher. Moreover, this change compared with the control group is more noticeable.

Overall, the results of descriptive statistics revealed that the treatment period has affected the students in experimental group as well as control group to increase their autonomy in learning; however, the increase in the experimental group was a lot more noticeable than the control group.

\subsection{Inferential Statistics}

4.2.1 Inferential statistics of Independent t-Test for the comparison of the mean scores of Autonomy Questionnaire of control and experimental groups in posttest.

Table 25. Inferential statistics of the mean scores of autonomy questionnaire of control and experimental groups in posttest

\begin{tabular}{|l|l|l|l|l|}
\hline & N & Mean & Std. Deviation & Std. Error Mean \\
\hline Control Group & 25 & 2.379 & .462 & .092 \\
\hline Experimental Group & 25 & 3.999 & .687 & .137 \\
\hline
\end{tabular}

As it is seen in Table 25, the experimental group (Mean Score= 3.999 and Standard Deviation $=0.687$ ) compared with the control group (Mean Score= 2.379 and Standard Deviation $=0.462$ ) shows a better performance in posttest.

Table 26. Inferential statistics of independent t-test for the comparison of the mean scores of autonomy questionnaire of control and experimental groups in posttest

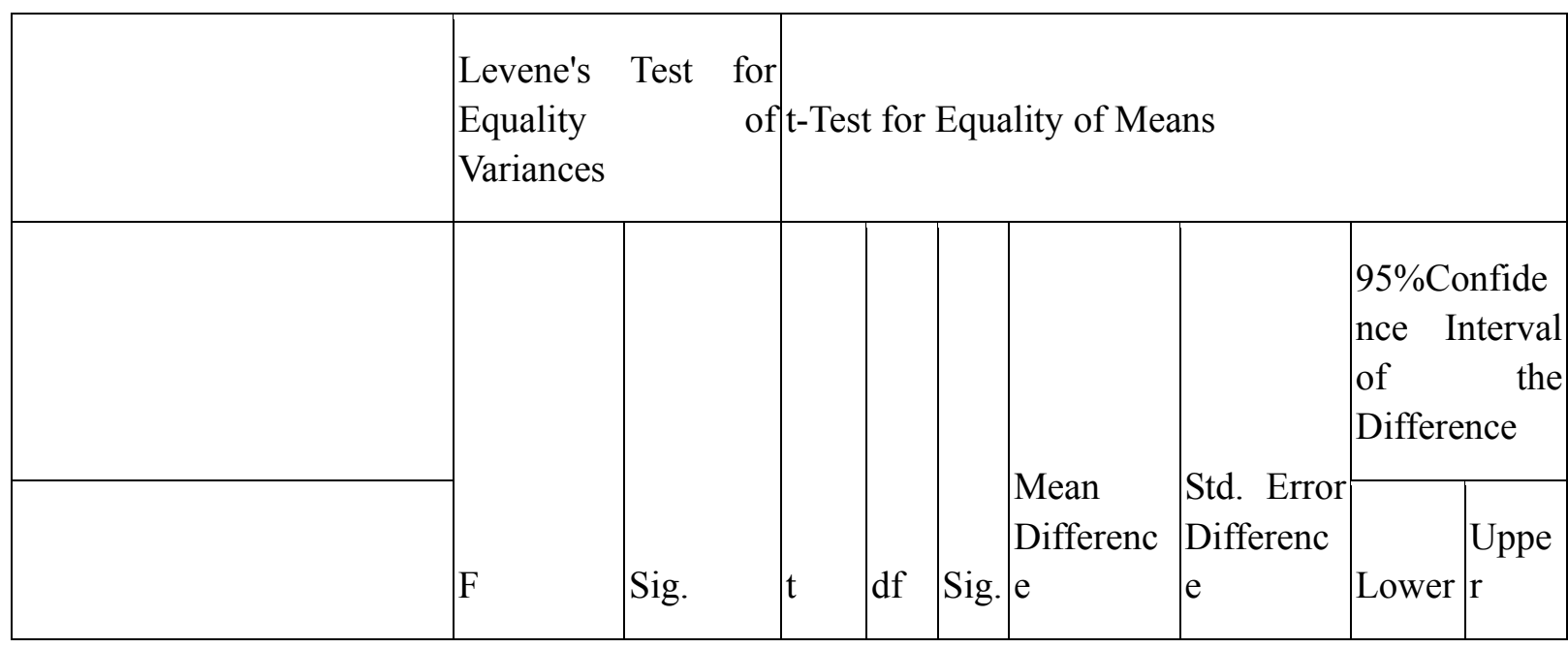




\begin{tabular}{|l|l|l|l|l|l|l|l|l|l|}
\hline Equal variances assumed & 20.10 & .00 & $\begin{array}{l}-9.7 \\
6\end{array}$ & 48 & .00 & -1.62 & .16 & -1.95 & -1.28 \\
\hline $\begin{array}{l}\text { Equal variances not } \\
\text { assumed }\end{array}$ & & & $\begin{array}{l}-9.7 \\
6\end{array}$ & 42 & .00 & -1.62 & .16 & -1.95 & -1.28 \\
\hline
\end{tabular}

As it is seen in Table 26, the results of Independent $\mathrm{t}$-Test $(\mathrm{t}=-9.76$, sig. $<\mathrm{P}(0.05))$ show a significant difference between control and experimental groups. Therefore, from the results, it can be inferred that Pot-luck, as an innovative technique of Project-Based Learning, has had a significant effect on increasing the autonomy of the learners.

4.2.2 Inferential statistics to answer the research question. Data analysis of the results of pre-test and post-test autonomy questionnaire was conducted to evaluate the null hypothesis. The null hypothesis was rejected since there was statistically significant mean difference between the pre and post-tests. Increasing the mean scores in Post-Test compared with Pre-Test especially in questions $(1,2,5,6,8,12,14,16,17,22,23$, and 25) of part one, indicates that the students' sense of autonomy after the treatment has increased dramatically. In addition, the increase of the mean scores of questions of part 2 of the questionnaire is another significant reason of improving the students' autonomy and rejecting the null hypothesis.

\subsection{Qualitative Results}

4.3.1 Qualitative results from Pot-luck Survey. Overall, they all believed that they learned speaking effectively; besides, they believed they improved their speaking ability noticeably in the Pot-luck course. The reason mentioned by them were mostly having a new and effective experience by Pot-luck which was different from traditional learning, having a friendly atmosphere, having fun besides learning, sharing and caring activities during Pot-luck time and the whole course, getting support through Pot-Log, feeling responsible for themselves and others, and last but not least, having a patient, supportive, and creative teacher.

Almost all students believe that it is easier to manage your learning in this kind of course compared with other courses. The reasons they mentioned were mostly feeling more responsible, feeling more supported by both the teacher and other students, being more active in the class, having less strict environment and more friendly relationships, and having more fun and which eases the learning.

All students unexceptionally admitted that learning in Pot-luck course is fun and enjoyable. They also mentioned that it was the best and the most enjoyable English course they have ever had. They mentioned different reasons such as having a friendly teacher, working in groups in a friendly and stress-free atmosphere, taking different roles and simulation of real life situations which was fun, but all the students mentioned that the most important factor was the nature of Pot-luck course and its special activities that suggested them having fun like a real life Pot-luck gathering. 
All students believed that in Pot-luck course they felt more autonomous and some even mentioned that they felt autonomous for the first time in a course. The reason they mentioned were feeling responsible for their learning, feeling a sense of responsibility for others that made them more autonomous to go for learning, feeling more independent from the teacher, feeling free to ask for new things from the teachers, students, or searching by themselves. The areas they mentioned were studying, learning new things, helping others, solving their problems, expressing their ideas, and even some mentioned that as a result they felt more autonomous in their real life outside the classroom and in their relationship with their siblings.

All students unexceptionally admitted that they really loved Pot-luck; besides, most of them wished for Pot-luck to become popular soon and to study other skills through this technique. The reasons they mentioned were mostly learning more, learning practically and effectively, learning with fun, feeling more responsible and independent, and, last but not least, having a new and different experience.

As suggestions, all of them asked the teacher to try hard to make Pot-luck more popular and they all hoped to experience Pot-luck for other skills. Some also suggested having some workshops for other teachers to teach them this technique.

\subsubsection{Qualitative results from Pot-log (Pot-luck Weblog).}

The results from analyzing the data (118 comments) from Pot log revealed that all the comments by the students showed their satisfaction of the course. Following, the general points of the students' comments have been mentioned.

They mentioned that Pot-luck was an innovative and creative idea, and Pot-Log was informative and helpful. They even said that the Pot-log slogan "Good Luck with Pot-luck" was very nice and motivating. Their comments showed that they were really satisfied with the course, Pot-luck technique, and the teacher. They stated that they enjoyed the class experience and the blog because the class atmosphere was active, energetic, and friendly with the focus on autonomy which was very useful and effective for improving their autonomy in learning. They admitted that the posts in the blog were also very useful and practical.

Many students mentioned that in Pot-luck course, they learned better and more effectively because they felt responsible and autonomous for their learning. They also admitted that Pot-luck experience was the first stress-free class experience and the best English- learning experience they have ever had. According to their posts, they enjoyed experiencing something modern, creative, and different. In addition, they hoped Pot-luck becomes popular for all skills and they were eager to attend any other classes with this technique

\section{Discussion}

In this study, since the researcher was the teacher of the class, she was in touch with the students directly; therefore, she was able to monitor the whole process much more clearly. Thus, interpreting the whole process helped obtain detailed information.

Findings of the study confirm that Pot-luck, as an innovative technique of project-based learning, had a significant effect on improving Iranian EFL learners' autonomy in learning. This 
finding of the study is in harmony with the findings of the previous studies regarding the positive outcomes related to students' learning.

The significant difference in achievement in this study was attributed to capability of Pot-luck as an innovative technique of project-based learning to enable students to feel more independent and autonomous to take responsibility over their learning and others' learning. Learning in a friendly and stress-free environment and experiencing Pot-luck as an innovative educational technique that considered students independent and autonomous who are actively involved in the process of learning and have control over their learning by getting more and more independent from the teacher, enabled students to feel more autonomous and responsible over their learning and the whole process of learning as a group. Moreover, Pot-luck taught students how to take responsibility over their problems in their real life and how autonomously take the first step towards solving their problems and towards their future success. Furthermore, they experienced how enjoyable is the feeling of being independent and autonomous.

The most interesting achievement of this study for the researcher as the one who was observing students closely as the teacher of the course was the fact that Pot-luck had a multi-faceted effect on the learners which not only helped students to feel more responsible over their learning and feel autonomous towards solving their problems but also helped them to feel more responsible over other students' learning and solving their problems as well in their groups. In other words, Pot-luck helped students to develop more responsible and autonomous and being more responsible and autonomous helped them to develop better peers to collaborate more to solve other students' problems. As a result, Pot-luck helped students to improve autonomy and autonomy helped to improve collaboration which was an amazing achievement of utilizing this technique.

\section{Conclusions}

The findings of the analysis of both quantitative and qualitative data confirmed that Pot-luck, as an innovative technique of project-based learning, had a significant effect on improving Iranian EFL learners' autonomy in learning as a $21^{\text {st }}$ century skill.

Besides, the findings of both quantitative and qualitative data provided enough evidence to reject the null hypothesis of the research. Moreover, the findings showed some specific points about the effectiveness of Pot-luck, as an innovative technique of project-based learning. The findings revealed that:

Being involved in the process of learning and problem solving, feeling autonomous and responsible for their learning and others' learning, working in groups and sharing information cooperatively and caring about each other's problems increased students' autonomy in Pot-luck course and created a positive attitude towards it.

It is noteworthy to mention that the psychological aspects of the whole idea of Pot-luck as a caring and sharing meeting and the comparison of learning with the concept of food and its vitality not only brought fun to the process but also emphasized the importance of learning and feeling autonomous for learning by sharing and helping; Therefore, it seems that it 
played the role of a catalyst in increasing and improving the efficiency of the technique.

Since one of the main purposes of this study was to evaluate the effectiveness of Pot-luck, the creative idea of the researcher as an innovative technique of project-based learning, the researcher, with the support of the findings of her research, therefore, is willing to proudly introduce her creative technique of Pot-luck, as an innovative technique of project-based learning to the scientific society, specifically ELT community.

It is noteworthy to mention that since Pot-luck is a technique rather than a method, it is very flexible to be used as a technique for other methods, approaches, theories, instructions, models, and Post Method ideas. Therefore, it is a technique which can be used in different contexts, based on the learners' needs and the teachers' decisions by just some subtle differences in order to be fine-tuned towards meeting different pedagogical purposes. Thus, Pot-luck is an innovative technique, which seems to bridge the gaps of different restrictive methods and makes a link towards the flexibility of Post Method era.

Replication of this study on different proficiency levels, different age samples, other language skills, other fields of studies, and in other contexts is suggested to provide more in-depth results. This would help to determine whether or not Pot-luck, as an innovative technique of project-based learning, is effective for a wider range of age groups, proficiency levels, other language skills, other fields of studies, and in other educational contexts.

\section{References}

Aiken, L. R. (1976). Update of attitude towards mathematics. Journal of Educational Research, 46(3), 293-311.

Ausubel, D., Novak, J., and Hanesian, H. (1978). Educational psychology: A cognitive view,2nd Edition, New York, Holt, Rinehart and Winston.

Barron, B. J. S., Schwartz, D. L., Vye, N. J., Moore, A., Petrosino, A., Zech, L., Bransford, J. D., \& The Cognition and Technology Group at Vanderbilt. (1998). Doing with understanding: Lessons from research on problem- and project-based learning. The Journal of the Learning Sciences, 7, 271-311.

Bartscher, K., Gould, B., \& Nutter, S. (1995). Increasing student motivation through project-based learning. Master's Research Project, Saint Xavier and IR Skylight.

Belland, B. R., Ertmer, P. A., \& Simons, K. D. (2006). Perceptions of the value of problem-based learning among students with special needs and their teachers. The Interdisciplinary Journal of Problem-based Learning, 1(2), 1-18. http://dx.doi.org/10.7771/1541-5015.1024

Boaler, J. (1997). Experiencing school mathematics: Teaching styles, sex, and settings. Buckingham, UK: Open University Press.

Bruner, J. (1973). Going Beyond the Information Given, New York, Norton.

Brush, T. \& Saye, J. (2008). The effects of multimedia-supported problem-based inquiry on 
student engagement, empathy, and assumptions about history. The Interdisciplinary Journal of Problem-based Learning, 2(1), 21-56. http://dx.doi.org/10.7771/1541-5015.1052

Buck Institute for Education. "PBD Overview” 05 July 2001. http://www.bie.org.

Davis, B. (2002). Motivating Students. Tools for teaching. Retrieved from the Web February 2, 2006. http://teaching.berkeley.edu/bgd/motivate.html

Finn, C. E. (1991). We must take charge: Our schools and our future. New York: Free Press.

Haladyna, T., Shaughnessy, J. \& Shaughnessy, M. J. (1983). A Casual Analysis of Attitude toward Mathematics. Journal for Research in Mathematics Education, 14(1), 19-29. http://dx.doi.org/10.2307/748794

Horan, C., Lavaroni, C., \& Beldon, P. (1996). Observation of the Tinker Tech Program students for critical thinking and social participation behaviors. Novato, CA: Buck Institute for Education.

Kehoe, C. Guzdial, M., and Turns, J. (1998). What we know about technological support for project-based learning. Proceedings of the Frontiers in Education Conference, 1997, IEEE: Pittsburgh, PA. pp. 918-922.

Kilpatrick, W. H. (1918). The project method. Teachers College Record, 19, 319-335.

Kulm, G. (1980). Research on Mathematics Attitude. In R. J. Shum Way (Ed.), Research in Mathematics Education (pp. 356-387). Reston, Va. NCTM.

Ma, X. (1997). Reciprocal relationships between attitude toward mathematics and achievement in mathematics. The Journal of Educational Research, 90(4), 221-229. http://dx.doi.org/10.1080/00220671.1997.10544576

Ma, X. \& Kishor, N. (1997). Assessing the relationship between attitude toward mathematics and achievement in mathematics: A Meta-Analysis. Journal of Research in Mathematics Education, 28(1), 26-47. http://dx.doi.org/10.2307/749662

Mergendoller, J. R., Maxwell, N. L., \& Bellisimo, Y. (2006). The effectiveness of problem-based instruction: A comparative study of instructional methods and student characteristics. The Interdisciplinary Journal of Problem-Based Learning, 1(2), 49-69. http://dx.doi.org/10.7771/1541-5015.1026

Mioduser, D., \& Betzer, N. (2003). The contribution of Project-based learning to high-achievers' acquisition of technological knowledge and skills. International Journal of Technology and Design Education, 18, 59-77. http://dx.doi.org/10.1007/s10798-006-9010-4

Nkwe, D. T. (1985). Teachers Attitude, with Special References to Mathematics Teaching.

Unpublished Med Dissertation, University of Witwatersrand, Johannesburg, South Africa.

Peck, J. K., Peck, W., Sentz, J., \& Zasa, R. (1998). Students' perceptions of literacy learning in a project based curriculum. In E. G. Stutevant, \& J. Dugan (Eds.). Literacy and community: The twentieth yearbook: A peer reviewed publication of the College Reading Association, (pp. 
94-100).Carrollton, GA: Beacon.

Penuel, W. R., \& Means, B. (2000). Designing a performance assessment to measure students' communication skills in multi-media-supported, project-based learning. Paper presented at the Annual Meeting of the American Educational Research Association, New Orleans.

Reigeluth, C.M. (1999) (Ed.). Instructional-Design Theories and Models: A New Paradigm of Instructional Theory, Mahwah, NJ, Lawrence Erlbaum Associates. Note: It seems that a new volume is under preparation (DSchneider 12:45, 13 May 2006 (MEST)).

Ravitz, J. \& Mergendoller, J. (2005). Evaluating implementation and impacts of problem-based economics in U.S. high schools. Paper presented at the Annual Meeting of the American Educational Research Association. Montreal, Canada. April, 2005.

Schoenfeld, A. H. (1989). Problem Solving in Context(s). In Randall I. Charles \& Edward A. Silver (Eds.), Teaching and Assessing of Mathematical Problem Solving, Research Agenda for Mathematics Education, vol: 3 Reston, VA. Lawrence Erlbaum Assoc. And Ntcm.

Shepherd, H. G. (1998). The probe method: A problem-based learning model's effect on critical thinking skills of fourth- and fifth-grade social studies students. Dissertation Abstracts International, Section A: Humanities and Social Sciences, September 1988, 59 (3-A), p. 0779.

Stepien, W. J., Gallagher, S. A., \& Workman, D. (1993). Problem-based learning for traditional and interdisciplinary classrooms. Journal for the Education of the Gifted, 16, 338-357.

Thomas, J. W. (2000). A review of research on project-based learning. Report prepared for The Autodesk Foundation. Retrieved May 18, 2009 from http://www.bie.org/index.php/site/RE/pbl_research/29

Tretten, R. \& Zachariou, P. (1995). Learning about project-based learning: Self-assessment preliminary report of results. San Rafael, CA: The Autodesk Foundation.

White, J. N. (2001). Socioeconomic, Demographic, Attitudinal, and Involvement Factors Associated with Achievement in Elementary School. Unpublished EdD Dissertation, East Tennessee State University, USA. 


\section{Appendix}

\section{Appendix 1: Learner Autonomy Inventory}

Based on Questionnaires to investigate the learner autonomy by Mojgan Nematipour (2012) \&Autonomous Learning Questionnaire by Arboleda (2010)

Direction: In order to investigate the learner autonomy, will you please put a check mark under the closest answer to the following questions. Thank you very much for your help and patience!

Please complete the following information:

Name (optional):

Age: teenagers $/$ in your $20^{\text {th }} / 30^{\text {th }} /$ more

Male/Female

Months /Years of studying English:

\section{Part I}

\begin{tabular}{|l|l|l|l|l|l|}
\hline Questionnaire Statements & Never & Rarely & Sometimes & Often & always \\
\hline $\begin{array}{l}\text { 1. I am interested in learning English. } \\
\text { 2. I think I have the ability to learn English } \\
\text { well. }\end{array}$ & & & & & \\
\hline 3. I plan for my English study. & & & & \\
\hline 4. I am very active in class. & & & & \\
\hline 5. I feel independent in learning English. & & & & & \\
\hline 6. I feel responsible for myself. & & & & & \\
\hline $\begin{array}{l}\text { 7. I feel responsible for my peer or other } \\
\text { members of the group. }\end{array}$ & & & & \\
\hline $\begin{array}{l}\text { 8. I don't wait for the teachers or parents to } \\
\text { ask me study. }\end{array}$ & & & & & \\
\hline $\begin{array}{l}\text { 9. I don't wait for the teachers or parents to } \\
\text { ask me finish a task. }\end{array}$ & & & & & \\
\hline $\begin{array}{l}\text { 10. I find I can finish my class activities in } \\
\text { time. }\end{array}$ & & & & & \\
\hline $\begin{array}{l}\text { 11. I keep a record of my study, such as } \\
\text { keeping a } \\
\text { diary, writing review etc. }\end{array}$ & & & & & \\
\hline $\begin{array}{l}\text { 12. I get volunteers in class activities. } \\
\text { 13. I help other students in my class. }\end{array}$ & & & & & \\
\hline $\begin{array}{l}\text { 14. During the class, I try to catch chances } \\
\text { to take part in activities such as pair/group } \\
\text { discussion, role-play, etc. }\end{array}$ & & & & & \\
\hline
\end{tabular}




\begin{tabular}{|l|l|l|l|l|}
\hline $\begin{array}{l}\text { 15. I am the one who starts the activities in } \\
\text { my group. }\end{array}$ & & & & \\
\hline $\begin{array}{l}\text { 16. If I don't understand something, I don't } \\
\text { mind asking questions from the teacher. }\end{array}$ & & & & \\
\hline $\begin{array}{l}\text { 17. If I don't understand something, I don't } \\
\text { mind asking questions from other students. }\end{array}$ & & & & \\
\hline $\begin{array}{l}\text { 18. I attend out-class activities to practice } \\
\text { and learn the language. }\end{array}$ & & & & \\
\hline $\begin{array}{l}\text { 19. I make self-exam with the exam papers } \\
\text { chosen by myself. }\end{array}$ & & & & \\
\hline $\begin{array}{l}\text { 20. I reward myself such as going } \\
\text { shopping, playing etc. when I progress. }\end{array}$ & & & & \\
\hline $\begin{array}{l}\text { 21. I choose books, exercises which suit } \\
\text { me, neither too difficult nor too easy. }\end{array}$ & & & & \\
\hline $\begin{array}{l}\text { 22. I know my strengths and weaknesses in } \\
\text { my English study. }\end{array}$ & & & & \\
\hline $\begin{array}{l}\text { 23. I take responsibility for my mistakes in } \\
\text { learning English. }\end{array}$ & & & & \\
\hline $\begin{array}{l}\text { 24. I try to improve myself in learning } \\
\text { English. }\end{array}$ & & & & \\
\hline $\begin{array}{l}\text { 25. I feel great when I finish a task by } \\
\text { myself. }\end{array}$ & & & & \\
\hline
\end{tabular}

Part II (Direction): For each question please choose just one answer which is the closest, and put a check mark in front of the option.

\begin{tabular}{|c|c|c|}
\hline \multicolumn{2}{|l|}{ Questionnaire Statements } & Yes \\
\hline \multirow{5}{*}{$\begin{array}{l}\text { 1. I study English in Jahan-e-Elm institute due } \\
\text { to: }\end{array}$} & 1. My parents' demand & \\
\hline & 2. $\quad$ Curiosity & \\
\hline & $\begin{array}{l}\text { 3. Getting a good job, help to my } \\
\text { major }\end{array}$ & \\
\hline & $\begin{array}{l}\text { 4. Being interested in English } \\
\text { culture, such as films, sports, music, } \\
\text { etc. }\end{array}$ & \\
\hline & 5. $\quad 3$ and 4 & \\
\hline \multirow{6}{*}{$\begin{array}{l}\text { 2. I think the learner-teacher relationship is that } \\
\text { of: }\end{array}$} & 1. Receiver and giver & \\
\hline & 2. Raw material and maker & \\
\hline & 3. Customer and shopkeeper & \\
\hline & 4. $\quad$ Children and partners & \\
\hline & 5. $\quad$ Explorer and director & \\
\hline & 1. Luck or fate & \\
\hline
\end{tabular}


Questionnaire Statements

3. I think my success or failure in English study
is mainly due to:

3.

2. English studying environment

3. Studying facilities(aids)

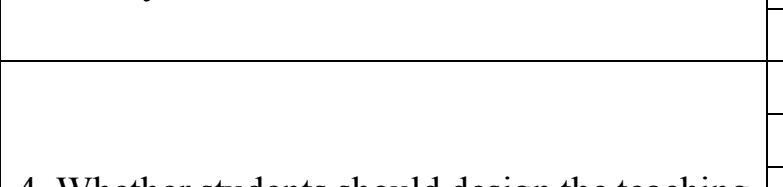

4. Whether students should design the teaching plan together with teachers or not, I:

4. Teachers

5. Myself

1. Strongly agree

2. Agree

3. Neutral

4. Disagree

5. Strongly disagree

1. Wait for others' answers

2. Think and ready to answer

5. When the teacher asks questions for us to answer, I would mostly like to:

3. Look up books, dictionaries

4. Clarify questions with teachers

5. Join a pair/group discussion

1. Let it go

2. Ask others

6. When I meet a question I don't know, mainly:

3. Guess the meaning

7. When I make mistakes in study, I'd usually
like the following ones to correct them:

4. 2 and 5

5. Search and try to find the answer by myself

1. Let them be

2. Teachers

3. Classmates

4. Others

5. Books or dictionaries

1. I usually try to learn new skills

2. I learn them following others

8. When I am asked to use technologies that I haven't used before(e. g. internet discussion in the class forum),

3. I feel worried, but anyway

4. I put it off or try to avoid it

5. I resist using them

1. I try to post some comments, or share my information or experience with others.

9. When I am asked to use technologies (e. g.

2. I read and follow others' our class blog "Pot-Log" or our class face book page),

\begin{tabular}{|c|c|}
\hline com & ments \\
\hline 3. & I feel worried, but anyway \\
\hline 4. & I put it off or try to avoid it \\
\hline 5. & I resist using them \\
\hline & Taking notes \\
\hline
\end{tabular}




\section{Questionnaire Statements}

\begin{tabular}{|c|c|}
\hline \multirow{4}{*}{$\begin{array}{l}\text { 10. } 1 \text { think the following way is the most useful } \\
\text { one in my English study: }\end{array}$} & 2. Mechanic memory \\
\hline & $\begin{array}{l}\text { 3. Doing exercises of grammar, } \\
\text { translation, words etc. }\end{array}$ \\
\hline & $\begin{array}{l}\text { 4. Classifying, grouping or } \\
\text { comparing }\end{array}$ \\
\hline & 5. Group discussion \\
\hline \multirow{5}{*}{ 11. I usually use materials selected: } & 1. Only by teachers \\
\hline & 2. Mostly by teachers \\
\hline & 3. by teachers and by myself \\
\hline & 4. $\quad$ Mostly by myself \\
\hline & 5. $\quad$ Only by myself \\
\hline
\end{tabular}

\section{Appendix 2: Pot-luck Survey}

1- What do you think of your achievement of effective learning of speaking in this kind of project-based course?

2- How easy/difficult is it to manage your learning in this kind of project-based course compared with other courses you have ever had? Why?

3- How autonomous do you feel in this kind of project-based course compared with other courses you have ever had? Why? In what area/s?

4- How Fun is learning in this kind of project-based course compared with other courses you have ever had? Why?

5- How do you like Pot-luck as an innovative technique of project-based learning? Why?

6- Any special opinion or suggestion regarding the improvement of Pot-luck technique would be appreciated.

Thanks a lot

\section{Appendix 3: Pot-log address}

http://www.hamidehbagherzadehhb.blog.com/

\section{Copyright Disclaimer}

Copyright reserved by the author(s).

This article is an open-access article distributed under the terms and conditions of the Creative Commons Attribution license (http://creativecommons.org/licenses/by/3.0/). 